\title{
Ethics of local government heads: A study of leadership in Surabaya, Bandung, and Purwakarta, Indonesia
}

\section{Etika pemerintahan kepala daerah: Studi kepemimpinan di Surabaya, Bandung, dan Purwakarta, Indonesia}

\author{
Mohammad Taufik ${ }^{*}$, Bambang Irawan ${ }^{2}$, Etika Khairina ${ }^{3}$, \\ Mochammad Iqbal Fadhlurrohman ${ }^{3}$, \& Paisal Akbar ${ }^{4}$ \\ ${ }^{1}$ Government Science Study Program, Faculty of Social and Political Sciences, \\ Mulawarman University \\ ${ }^{2}$ Master of Public Administration, Faculty of Social and Political Sciences, Mulawarman University \\ ${ }^{3}$ Department of Government Affairs and Administration, Jusuf Kalla School of Government, \\ University of Muhammadiyah Yogyakarta \\ ${ }^{4}$ Doctoral Program in Political Islam-Political Science, Jusuf Kalla School of Government, \\ University of Muhammadiyah Yogyakarta \\ Address: ${ }^{1,2}$ Jalan Muara Muntai, Gn. Kelua, Samarinda, East Borneo, Indonesia 75411 \\ ${ }^{3,4}$ Geblagan, Tamantirto, Bantul, Special Region of Yogyakarta, Indonesia 55184 \\ E-mail: mohammad.taufik@fisip.unmul.ac.id
}

Article History: Received 07 October 2020; Accepted 18 October 2021; Published Onlie 29 November 2021

\begin{abstract}
The most significant aspect of a leader's behavior is ethics because it is a guideline for interacting, acting, and involving in government in an ethical manner without abusing power. This article aims to find out how the ethics of regional heads are applied in the administration of regional government. The research method used was qualitative with a literature study approach. Data collection was done by literature study by collecting various materials from books, journals, research results, and mass media (news). The results of research conducted on three districts/ cities in Indonesia involving three leaders of the Mayor of Surabaya, the Mayor of Bandung, and the Regent of Purwakarta in 2015 show some real examples of regional heads who apply ethical values in their leadership, which can be seen from their performance and competence as well as ideas (innovation) and relationships with the community. It has gone well by applying ethical principles in its performance such as accountability, transparency, legal assurance, and justice. Competence in leadership includes the application of ethical values including emotional intelligence, self-management, social awareness, and relationship management. This study concludes that government ethics greatly influence the implementation and desired results, as well as on leadership, which will affect the performance carried out.
\end{abstract}

Keywords: government ethics; leadership; regional head

\begin{abstract}
Abstrak
Aspek paling penting dari perilaku seorang pemimpin adalah etika karena merupakan pedoman untuk berinteraksi, bertindak, dan terlibat dalam pemerintahan secara etis tanpa menyalahgunakan kekuasaan. Artikel ini bertujuan untuk mengetahui bagaimana etika kepala daerah diterapkan dalam penyelenggaraan pemerintahan daerah. Metode penelitian yang digunakan adalah kualitatif dengan pendekatan studi literatur. Pengumpulan data dilakukan dengan studi kepustakaan dengan mengumpulkan berbagai bahan dari buku, jurnal, hasil penelitian, dan media massa (berita). Hasil penelitian yang dilakukan di tiga kabupaten/kota di Indonesia yang melibatkan tiga pimpinan Walikota Surabaya, Walikota Bandung, dan Bupati Purwakarta tahun 2015 menunjukkan beberapa contoh nyata kepala daerah yang menerapkan nilai-nilai etika dalam kepemimpinannya, yang dapat dilihat dari kinerja dan kompetensi mereka serta ide (inovasi) dan hubungan dengan masyarakat. Kinerja kepemimpinan berjalan dengan baik dengan menerapkan prinsip-prinsip etika dalam kinerjanya seperti akuntabilitas, transparansi, kepastian hukum, dan keadilan. Kompetensi kepemimpinan meliputi penerapan nilai-nilai etika yang meliputi kecerdasan emosional, pengelolaan diri, kesadaran sosial, dan pengelolaan hubungan. Studi ini menyimpulkan bahwa etika pemerintahan sangat mempengaruhi pelaksanaan dan hasil yang diinginkan, serta pada kepemimpinan, yang akan mempengaruhi kinerja yang dilakukan.
\end{abstract}

Kata kunci: etika pemerintahan; kepemimpinan; kepala daerah 


\section{Introduction}

The government becomes an actor who plays an important role in the administration of a country. One of the administrations of government is to provide services to the community. Currently, the government's public services have many weaknesses that hinder them from fulfilling the quality expected by the community. This is marked by the occurrence of various public complaints submitted through the mass media in order to cast an unfavorable image on the government. Given that the main function of the government is to serve the community, it needs to continue to improve the quality of its services. Failure to provide services will harm the community because they will lose their rights as customers who must be served by the government and the state both in terms of state finances and the budget that has been issued. As stated by (Anggraeni 2014), negligence or neglect of obligations in public services carried out by the government including individuals who help the government in providing public services can cause material and non-material losses to the community and have already harmed the state.

Government performance problems almost occur in every area such as in the implementation of convoluted service procedures, time and cost uncertainty, lack of awareness of the officers in understanding their position as public servants to be friendly and polite, and the emergence of illegal levies carried out by the apparatus themselves or the community. Such phenomena have caused a decrease in people's interest in government agencies that directly provide services, resulting in dissatisfaction. In 2002 there was a study conducted a survey that examined the performance of government organizations in providing public services in Indonesia. The survey was carried out by (Dwiyanto 2002) entitled "Governance and Decentralization Survey (GDS)", involving 20 provinces in Indonesia. The results of the survey stated that the government's performance in providing public services in terms of the time required for a service is often not regulated. Local governments do not provide a clear time or deadline for completing a service.

The absence of regulations that clearly state the required time in completing services causes the organizers to act arbitrarily, resulting in uncertainty in all types of services. The survey conducted gave an understanding that dissatisfaction in public services has been going on for a long time. Other studies revealing this issue were conducted by (Baru \& Sripeni 2019), showing that implementation of services has not been able to encourage the improvement of public services. It is because the tendency of the public bureaucracy is more oriented to serving the interests of the authorities than the interests of the community. As a result, the bureaucracy becomes increasingly distant from its mission as public servants. The practice of public services so far is still considered procedural, convoluted, and slow in its completion (Fernanda 2003, Sumarto 2017). According to (Maani 2010), the very high uncertainty in services encourages residents to pay extortion to officers so that service certainty can be immediately obtained and resolved.

Public dissatisfaction with government services and performance is also the reason behind the bureaucratic reform (Kementerian PANRB 2010), one of the areas that need to be reorganized is the performance of the bureaucracy/government. Furthermore, the ineffective and inefficient performance of the bureaucracy as a public servant has become one of Indonesia's problems and a bad image for the country. Therefore, President Jokowi in his first period in 2014-2019 raised and included the issue in one of the priority agendas of the nine priorities known as Nawa Cita, that in the future the government will continue to strive to build clean, effective, and democratic governance, reliable and transparent.

In simple terms, ethics can be understood as a set of value systems or normative standards containing values, morals, norms, and things that are considered good (Nugroho 2013, Hastiyanto 2017). According to (Santoso \& Dewi 2019), ethics can also be interpreted as a standard regarding right and wrong, good and bad, and whether or not an action is performed according to moral rules. Ethics can be used as the basis for thinking and acting for a government administrator in carrying out government activities (Lontoh et al. 2019). Furthermore, Yuningsih (2019) explains that ethics in public services refers to 
standards, norms, legal regulations, and social values that guide and regulate the behavior of public officials. According (Maani 2010), values and morals that are considered good will be a guide in acting and carrying out what is believed. A government with high ethics and morality in carrying out its government authority has high responsibility and respect for the demands of the aspirations and interests of the people it serves.

According to (Dwiyanto 2006), public service bureaucrats need ethics to provide services to the community. Therefore, the community's demands for public services are closely related to moral and ethical issues. Public service activities cannot be separated from the human element, morality, and integrity which are needed in warding off disease or problems in the bureaucracy, such as corruption. Objective conditions show that the implementation of public services is still hampered by an ineffective and inefficient government system and a lack of competent human resources of the apparatus. This is evidenced by the existence of complaints from the public either directly or through the mass media regarding service procedures, time, and finance.

According to Fatah (2013), leaders must have the capacity, capability, and integrity as well as be an example and understand ethical and moral values and be able to realize them in carrying out their leadership process. According to Widyani (2020), unethical behavior will have an impact on weak government and bad institutions in the eyes of the community. In line with that, Yuningsih (2019) says that the main essence of power is a moral responsibility so that in government, especially every policy, ethical and moral characteristics are very attached as an effort to realize prosperity and become the point of public service (Muchtarom 2012, Yunus 2014). Ethics and morals are not about right or wrong but what should and should not be done (Endah 2018). Therefore, ethical values in policy implementation must be used as a standard of assessment by the government. The ethical and moral dimensions of government are not about right and wrong but ethical or appropriate and knowing what the community needs because ethical values will be right in their place if they are carried out and benefit the public.

Paisa et al. (2019) argue that the importance of ethics in political leadership will directly explain which behavior is ethical and which political behavior is unethical. Deviations and fallacies such as corruption carried out by regional heads as leaders make the government violate regulations and some of them deviate from religious teachings and cause the government to become chaotic. This is because corruption is a crime that is often committed by people who have power and position. The corruption case such as committed by Edhy Prabowo (Ryn 2021), the case of Jambi's Non-active Governor, Zumi Zola (Gabrilin 2018), and several other cases of frauds and failures show that that there has been a decline in the ethics of the elites or government actors as leaders. Corruption as an unethical phenomenon that often occurs in the Indonesian government that harms society is also a manifestation of faulty ethics and morals of public officials. It is closely related to power (Awaludin 2017). Corruption occurs as a result of the abuse of absolute and unlimited power that can be a trigger for continuous corruption.

The phenomena mentioned above and the current conditions in the form of challenges faced such as increasing/developing community needs and increasing global competition become challenges for the government to provide service-oriented results (general satisfaction). However, in terms of public services, it can be said that benefits to the community have not qualified. This can be seen from the results of the Corruption Crime Statistics reported by the KPK from 2015-2020 showing the number of corruption cases based on agency, profession/position, patients with permanent legal force, and region (KPK 2020). Corruption shows that many government administrators do not include ethical and moral values in running the government, as can be seen in Table 1.

The data show that some leaders do not understand their roles as a leader. Such diseases almost occur in every regional government. Still, few provincial governments have succeeded in providing service and satisfaction to the community and regional development as a manifestation of government ethics in providing community services. It is shown by the leadership of Tri Rismaharini when she was the mayor of Surabaya, Ridwan Kamil, and Dedi Mulyadi. The three leaders were able to give peace to the 
community and win the people's hearts through their performance results. The three leaders even went directly to the field to find out the problems in each of their cities as stated earlier that ethics and morality must exist at every phase in providing services to the community. According to (Ismiyarto 2016), ethics starts with the preparation of service policies for management to achieve the ultimate goal of service, which is to uphold accepted moral values. Therefore, truth, justice, and freedom must be implemented in leadership.

Table 1.

Corruption crime 2015-2020

\begin{tabular}{|c|c|c|c|c|}
\hline Case & $\begin{array}{l}\text { Institutions and } \\
\text { types of cases }\end{array}$ & Position & Inkracht & Region \\
\hline 2015 & 57 cases & 62 cases & 37 cases & 57 cases \\
\hline 2016 & 99 cases & 99 cases & 70 cases & 99 cases \\
\hline 2017 & 121 cases & 123 cases & 84 cases & 121 cases \\
\hline 2018 & 199 cases & 260 cases & 109 cases & 199 cases \\
\hline 2019 & 145 cases & 154 cases & 142 cases & 145 cases \\
\hline 2020 & 91 cases & 110 cases & 70 cases & 91 cases \\
\hline Total & 712 cases & 808 cases & 423 cases & 172 cases \\
\hline
\end{tabular}

In this context, the actors involved in each phase will be considered, including whether they prioritize their interests or the public interest over other concerns. As the community that is being served, the public can judge whether the actor is honest in formulating policies, fairly, or whether they commit fraud, corruption, or exploits their positions. Therefore, the context is closely related to the ethics and morality of the actors involved or the behavior of the leaders in organizations and regional heads. Matters such as corruption, legislative ethics, regulatory ethics, conflicts of interest, bribery, and issues of honesty and transparency in government are included as governance ethics (Taufiqurokhman \& Satispi 2018). Furthermore Setiawan \& Fauzi (2019), government ethics does not only concern individuals as members of the organization but also the ethics of the organization and the profession of the organization whose implementation is reflected in the ethical values that exist in the legislation, religious values, social values, culture, and other values related to the administration of state government. A study by (Nugroho 2013) shows that there are five principles of ethical leaders, including fairness, transparency, responsibility, efficiency, and no conflict of interest.

The term leadership is related to ethics and morals. A leader has a different character and style so that the variety showed also varies. These characters and styles become one of the determinants of whether a leader is ethical and moral (Sumarto 2017). Ideally, the behavior of a leader and government apparatus should be based on government ethics. Ethics and morality that exist in government leaders can minimize fraud that occurs due to unethical treatment, such as corruption (Satria 2020). Therefore, ethics and morals are crucial for leaders. The public is led to be more critical and dare to voice their wishes as well as to control the performance of the government to be more flexible, open, accountable, and simple. The success and failure of a regional head both in serving the community and regional development, as well as cheating and fraud by regional heads, cannot be separated from the ethics and morals of a regional head. Therefore, the leadership style of the regional head, including the characteristics, attitude, and habits will lead to the ethics and morality of a leader (regional head).

This paper is interesting to discuss because the government's performance is related to government ethics in providing services to the community. This is also in line with the statement that the issue of ethics and morality is a fundamental problem in public services which is realized by all levels of government and society (Lusiawati 2020). This study aims to analyze government ethics in terms of regional heads' leadership by prioritizing morals and values to carry out government performance. Therefore, according to (Kusumawati 2019), ethics is an important element and greatly affects the success of the service. Government ethics in the leadership of regional heads as an instrument of driving local government is an interesting thing to study. The ability of a person to move others and carry out 
what is instructed will become consistency and responsibility for the leader, as stated (Hastiyanto 2017). The success of leadership depends on several elements such as requirements, characteristics, traits, principles, and leadership style. Different implementation practices, cultures, and political leadership styles distinguish each leadership highlighted by regional heads in carrying out development. Therefore, this paper would examine government ethics implemented by regional heads' leadership in Indonesia (Surabaya, Bandung, and Purwakarta).

\section{Research Method}

This paper used a qualitative descriptive method with a literature study approach. The qualitative research method is used to explore and understand a central phenomenon (Raco 2018). The selection of the subject of this paper was based on leadership figures including Tri Rismaharini, Ridwan Kamil, and Dedi Mulyadi who have succeeded in leading their regions by raising innovation and change for their regions so that it is good to emulate their leadership. This is also based on the fact that regions led by good and innovative leadership can become the regions that succeeded. The data used in this paper was sourced from secondary data. Secondary data is data collected from other sources which can be in the form of readings or literature and various other data sources (Raco 2018). Secondary data in this paper was sourced from publications of journals/articles and research documents (books and government reports) as well as other manuscripts related to this paper and online media.

The stage of selecting the review literature begins with the process of selecting articles and understanding all related articles that have the same subject. After that, the discussion was segmented by taking a common thread which was then developed into a new section. The data were analyzed using a step or analysis model by Miles and Huberman, which is the Triangulation model. (Sari \& Asmendri 2018) stated that literature study writings can be analyzed using a triangulation analysis model (Sugiyono 2005) including data reduction by summarizing, selecting the main elements, and focusing on the important elements obtained from the literature study. The data is summarized and selected to provide a clear picture. Furthermore, data presentation, which is carried out in the form of brief descriptions, charts, relationships between categories, and the like. However, in this paper, the presentation is done in the form of narrative text. The last stage is drawing conclusions and verification, which are conducted to search for conclusions or concluding the data that has been written.

\section{Results and Discussion}

\section{Governance ethics in local government administration}

In the administration of government, both central and regional, the leader and the bureaucracy as public servants are expected to have mental attitudes and behaviors that reflect the character and ethical principles in their actions so that it will be a reference for balancing their actions and words that are sourced from moral policies, especially justice in acting. Ethics is the determination of guidelines to do what is right and not to do what is wrong. It is believed to bring life to a good condition and not harm the lives of others (Lontoh et al. 2019). In government, it is an indication of value to the government and society in taking an action, relating to what is right and what is wrong as well as what is ethical and what is unethical (Sumarto 2017). Government ethics relates to the powers that must be practiced by government officials and employees. Therefore, government ethics discusses the behavior of government administrators, especially the use of power and authority including the legitimacy of power. Government ethics is teaching to behave properly and correctly by the values of virtue related to human nature. As stated by (Amiruddin 2017), government ethics refers to a special professional code of ethics for those who work in the realm of government. Government ethics involves rules and guidelines on how to behave and act in several different groups in government institutions.

When the morality of policymakers is low, the quality of the resulting policies is very low. This is in line with arguments that ethics not only be a success factor but also a trigger in thwarting policy objectives, organizational structure, and public management (Keban 2014). Ethics in the administration 
of the government is essential as the professionalization of the apparatus in carrying out their duties/ services. The Principles of Ethics in the administration of government were also developed by the Josephson America Institute (Gie 2006). The Government of Indonesia also issued regulation Number 81 of 1993 concerning Guidelines for the Management of Public Services which need to be guided by government agencies that are used as principles in the administration of government, including; The first, accountability, highlights the importance of developing ethics in government as the main aspect that must exist in public officials/regional leaders. The ethical need in government is at least driven by the need to realize an accountable, clean, and accountable government. Unethical governments tend to show bad behavior to the community such as not interacting with the community, closing community access, working slowly in serving and meeting the needs of the community, causing government performance to be ineffective and inefficient and not in accordance with the concept of good governance. The obligation to provide accountability to the community is an absolute aspect that leaders must do. The successes and failures that occur in the government system are closely related to ethics and morals (Budiyono 2012). Unethical behavior that comes out of ethical and moral values and the inability to account for its performance is a sign of the destruction of a government.

The second, transparency, indicates that immoral actions in government such as fraud and corruption show weak government and low openness to the public. Sympathy and good communication with the community cannot be separated from the behavior, character, and ethics of a leader or government apparatus in realizing transparency. The government has an important and specific position in life and in realizing good governance. It is demanded to be open to input and suggestions from the public. According to Yuningsih (2019), the realization of transparency can be applied in carrying out its basic functions, including serving, building, and empowering the community. Therefore, the principle of transparency is needed in the basic functions of government as the driving wheel of government. In government, a code of ethics/morals or right rules of conduct has been made which provides rules for correct behavior that should be obeyed and shown by public officials as service providers to the community. If it is widely understood and studied, the religious values and moral ethics of Pancasila are sufficient to guide work or behavior, and the problem is how to implement these values in behavior. It is because referring to the formulation of the code of ethics made by the government is still very limited to some services and circles such as legal and medical experts. Solutions that contain the principle of openness can be accepted and accounted for by the leader and vice versa, an irresponsible way does not contain the value and meaning of openness. Absolute benchmarks regarding right and wrong do not exist in life, but they cannot be separated from ethical factors and sources such as religion, culture, and society. Understanding is the basis for the need for ethics in organizations and helps give the right meaning to its understanding.

The third, legal certainty, requires the government officials to apply the concept of good governance. In the context of good and clean governance, the form of professionalism of the government apparatus is to emphasize more on the clear quality of the work that can be felt by the public. Understanding of the concept is growing in achieving the objectives of the concept of good governance, ethics, morals, and ethical attitudes are needed in its application and implementation by the public apparatus. This is in line with what was conveyed by Yusuf (2017) that administration of government, which refers to the actions taken by government officials or public officials is always not only seen from a formal measure as a procedure but can represent the interests of the community by always being consistent with values of truth. All programs or policies concerning the public interest must be carried out based on the law. Legal guarantees will provide justice for every public policy, even if the conflict resolution in a program or policy will be based on applicable laws and regulations. The fourth, fair treatment, shows that a fair attitude that does not prioritize one group and is not discriminatory is one of the ethical behaviors in government. The government requires justice and honesty that will instill trust in the hearts of the people to gain recognition and strong legitimacy. Justice will accelerate achieving good governance so that the opportunity to obtain equal rights must be given in the path or concept of justice. No group should feel excluded or prioritized and they should get the same rights, which is a manifestation of the existence of ethical and moral values in the administration of the government. 


\section{Leadership ethics and phenomenon of public officials}

Ethical behavior becomes essential in the leadership of local governments, where in government it is always linked to the values of virtue related to the basic rights of citizens as social beings. To be able to carry out their duties and obligations, government officials need to act based on ethics as guidelines or directions so that they do not go out of the path which will undermine the authority of the government as a state instrument. Low morals and ethics in carrying out government duties result in fraud, such as regional heads being caught in corruption cases. Forms of bureaucratic corruption in public services can be identified from behaviors such as bribery, embezzlement, abuse of authority, illegal and unreasonable acquisition of goods or services, counterfeiting, poor service quality, and carelessness. All of which are included in unethical behavior and should not be done by a leader/bureaucracy.

Nowadays, in the era of democratization, the behavior of government leadership is required to direct orientation and focus on the public interest above personal/group interests. This can be realized through ethical and moral improvements in leading such as listening to people's aspirations, not making oneway decisions, accepting criticism and input from the public for further improvement. Ethics can be sourced from religion, Pancasila, although each region has differences as stated by Budiyono (2012) that ethical values differ from one place to another due to the ethical sources owned by the community in that place, including in terms of religion, culture, and customs. Government leadership is faced with far more complex and global problems than today. Therefore, every leader is expected to have and uphold ethical and moral values in his or her leadership as well as strong religiosity. As a state apparatus, the government is expected to be able to demonstrate ethical attitudes and behavior and include conscience. In addition to the demands for creative and competitive leadership competence characteristics in the global era, governments are expected to understand and practice ethical and moral leadership and behave ethically in every interaction.

Good and competent leadership is demonstrated by Tri Rismaharini as the previous Mayor of Surabaya, Dedi Mulyadi as the Regent of Purwakarta, and Ridwan Kamil as the Mayor of Bandung. The three leaders are among several public officials who instill ethical and moral values with innovation and empathy for the community in regional development policies and programs so that they are attractive and inspirational for the community, other regional heads, and local communities. Professional governance not only requires technical and leadership competence but also ethical competence as ethical behavior and is considered good. Ethical competence will require leaders to be more sensitive, caring, and nondiscriminatory. An ethically competent leader will be able to realize the values of honesty, solidarity, justice, equality. Based on several kinds of literature or studies, Table 2 shows the competence of regional heads who apply ethical values and behavior in their leadership as regional heads.

The three regional heads are examples of regional head leadership who lead with ethical values. Emotional intelligence and self-management, social awareness, and relationship management are mastered and exist in leadership. Those regional heads succeeded in bringing the name of the region and advancing the region with competencies such as making breakthroughs in their leadership, resulting to be the public spotlight.

The previous Mayor of Surabaya, Mrs. Tri Rismaharini, has a spirit of competence in leading. She applies ethical values that she developed in herself and knows how to utilize and maximize her potential so that she won the trust of her community by serving for two periods. Many development successes were carried out during her leadership such as in the case of closing the Dolly localization which had never dared to be carried out by previous mayors. Mrs. Risma first used an approach to prostitutes and pimps by explaining that this policy was the best decision that must be carried out in the interests of everyone. She also provides provisions in the form of skills through the training provided so that the prostitutes and pimps have the provisions to live a new profession and life later. Based on this description, Tri Rismaharini applies the value of caring and non-discrimination in policy delivery (DPMPTSP 2020). 
Table 2.

Regional head competence

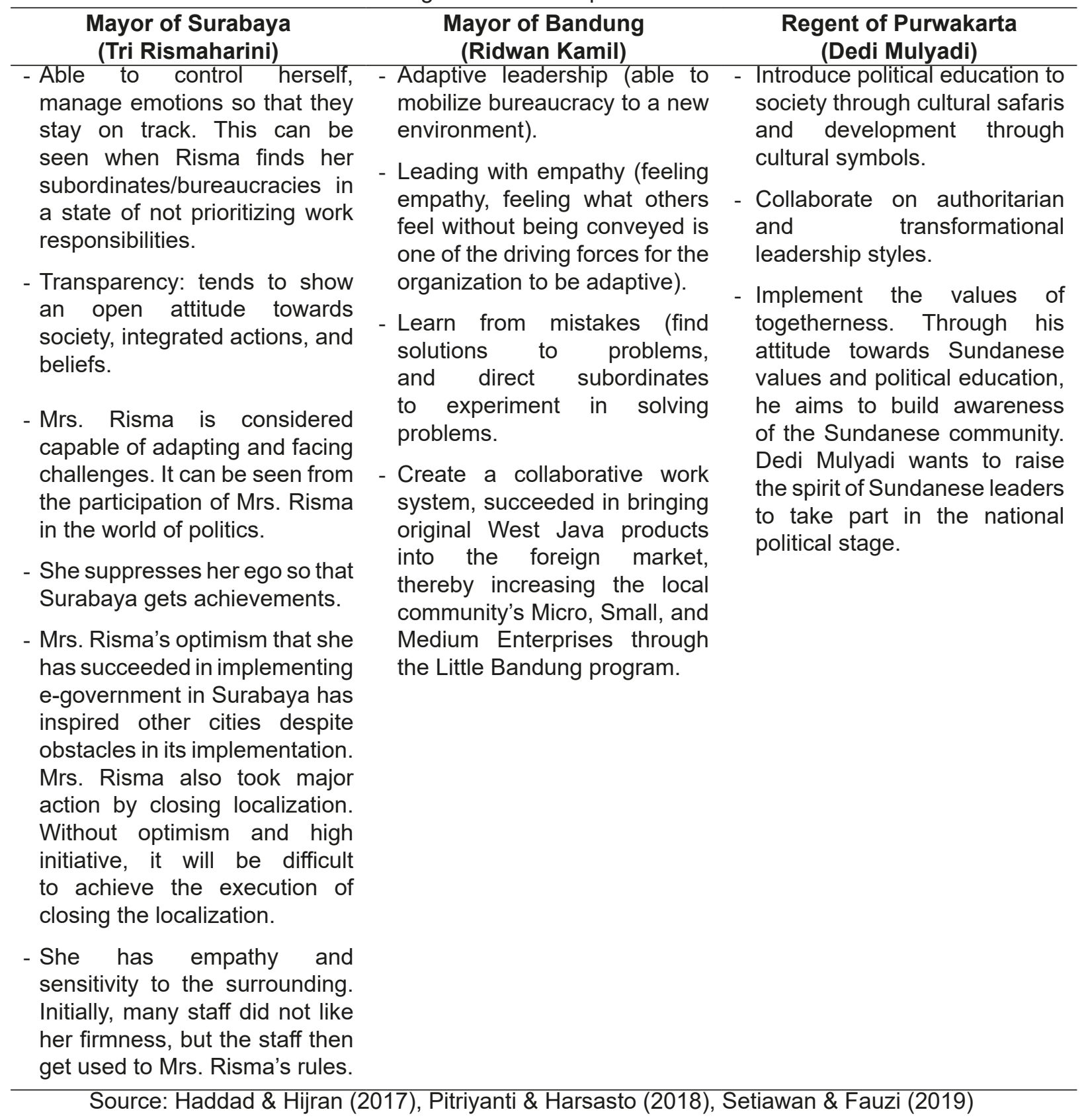

The Mayor of Bandung, Ridwan Kamil, like Mrs. Risma, applies ethical values to create innovations in regional development. He is also considered to have a strong empathetic spirit towards his people. During one year of his reign, Ridwan Kamil formed the Development Acceleration Team (DAT) and relocated to the West Java government center. During his reign, Ridwan Kamil strongly prioritized the participation of the community in determining the direction of policy. He formed many mayoral advisory teams that came from elements of society. He has also succeeded in building a small and medium-sized micro business for the residents of Bandung with the Little Bandung program. This program allows original West Java products to be sold worldwide which has an impact on the welfare of the people of West Java (Humas Bandung 2018). Dedi Mulyadi, the Regent of Purwakarta in 2015, was able to inspire and educate the community by the way he led. He applied political education to the community, inspired the community to continue to preserve local wisdom by leading Sundanese culture, but still able to create people who are dynamics. 
The Regent of Purwakarta has reflected his attitude as a leader with his Sundanese character. He succeeded in influencing the people of Purwakarta to realize the vision of "Purwakarta with Excellent Characteristics" by preserving the Sundanese culture which is the ancestral culture of the Purwakarta people. It is proven that at this time, the people of Purwakarta seem to be reuniting with the Sundanese culture which was once lost. It is also strengthened with the many characteristics of Sundanese culture that are again displayed in the Purwakarta area both from buildings and daily habits. Dedi Mulyadi wants Purwakarta to have a character/differentiation from other regions. However, the Sundanese culture that is highlighted in development does not necessarily discriminate against immigrants in Purwakarta who are not from the Sunda region. Dedi Mulyadi combines a transformational leadership pattern or style with an authoritarian style in leading Purwakarta Regency. The pattern of transformational leadership is carried out by Dedi Mulyadi in attitudes or actions of daily behavior by always being consistent with the Sunda style using pangsi and iket. Every word of Dedi Mulyadi has values contained in it, especially those related to Sundanese values (Haddad \& Hijran 2017).

Based on secondary data with literature DPM-PTSP Surabaya, news online of Liputan 6, and the study conducted by (Haddad \& Hijran 2017), the ethical principle becomes a parameter for each regional head studied. Tri Rismaharini has a leadership pattern with the characteristics of sincerity, honesty, innovation, integrity, confidence, achievement, initiative, optimism, and excellent service. Dedi Mulyadi practices informal leadership. His unconventional leadership style by developing a pattern of cultural arts diplomacy made him be able to bring fresh air to the political map of West Java at that time. Dedi Mulyadi's leadership pattern was a transformational leadership that was slightly authoritarian because apart from being successful in motivating the people of Purwakarta to return preserving Sundanese culture, he also raised the spirits of Sundanese leaders to take part in the national political stage. Ridwan Kamil's leadership is similar, which is a combination of Rational-Empirical and Normative-Reeducative approaches. For the leadership model, all three exemplify transformational leadership, but Ridwan Kamil combines it with a charismatic leadership style. Although there are slight differences, these approaches and leadership models make them successful leaders by behaving ethically in administering the government.

\section{Conclusion}

In both central and regional government administration, state servants, leaders, and bureaucracies are expected to have mental attitudes and behaviors that reflect the characteristics and ethical principles in acting as a balancing reference. Their actions and words come from moral wisdom, especially justice in action. Ethics is believed to bring life in good conditions and not harm the lives of others. All programs or policies concerning the public interest must be carried out by law. Legal guarantees will provide justice for every public policy, although conflict resolution in a program or policy will be based on applicable laws and regulations. Ethical behavior is critical in local government leadership. Ethics in government is always related to virtue values related to the fundamental rights of citizens as social beings. The pattern of government requires justice and honesty that will instill trust in the hearts of the people to gain substantial recognition and legitimacy.

Leadership ethics of public officials' ethical behavior is fundamental in local government leadership. Good and competent leadership was demonstrated by Tri Rismaharini as the previous Mayor of Surabaya, Dedi Mulyadi as the Regent of Purwakarta, and Ridwan Kamil as the Mayor of Bandung. The three leaders are public officials who instill ethical and moral values with innovation and empathy for the community in regional development policies and programs to be attractive and inspiring to the community. Emotional intelligence and self-management, social awareness, and relationship management are mastered in their leadership. Professional governance requires technical competence and leadership and ethical competence as ethical behavior and is considered good. Ethical competence will require leaders to be more sensitive, caring, and non-discriminatory. An ethically competent leader will realize the values of honesty, solidarity, justice, equality. 


\section{References}

Amiruddin A (2017) Inovasi peran pemerintah desa dalam kebijakan pariwisata di Kota Batu. JPSI (Journal of Public Sector Innovations) 2 (1):26-32. http://dx.doi.org/10.26740/jpsi.v2n1.p26-32.

Anggraeni TD (2014) Menciptakan sistem pelayanan publik yang baik: Strategi reformasi birokrasi dalam pemberantasan korupsi. Jurnal Rechts Vinding: Media Pembinaan Hukum Nasional 3 (3): 417-433. http://dx.doi.org/10.33331/rechtsvinding.v3i3.34.

Awaludin A (2017) Ideologi etis penyingkap korupsi birokrasi. Pandecta: Research Law Journal 11 (2):189-201. https://doi.org/10.15294/pandecta.v11i2.7852.

Baru BM \& Sripeni R (2019) Potensi korupsi birokrasi publik dalam penyelenggaraan pelayanan publik. Seminar Nasional Sistem Informasi 3 (1):1865-1877.

Budiyono (2012) Menjaga etika dalam berpolitik. Jurnal Pancasila dan Kewarganegaraan 1 (1):51-60. http://doi.org/10.25273/citizenship.v1i1.3736.

Endah K (2018) Etika pemerintahan dalam pelayanan publik. Moderat: Jurnal Ilmiah Ilmu Pemerintahan 4 (1):141-151. http://dx.doi.org/10.25147/moderat.v4i1.1088.

DPMPTSP (2020) Keberhasilan pimpin Kota Surabaya, antarkan Tri Rismaharini jadi Mensos, 23 December. [Accessed 02 January 2021]. http://dpm-ptsp.surabaya.go.id/v3/detailpost/ keberhasilan-pimpin-kota-surabaya-antarkan-tri-rismaharini-jadi-mensos.

Dwiyanto A (2002) Reformasi Birokrasi Publik di Indonesia. Yogyakarta: Pusat Studi Kependudukan dan Kebijakan UGM.

Dwiyanto A (2006) Mewujudkan Good Governance Melalui Pelayanan Publik. Yogyakarta: Gadjah Mada University Press.

Fatah MA (2013) Kepemimpinan pemerintah daerah dalam perspektif etika publik. Journal Of Chemical Information And Modeling 53 (9):1689-1699. https://doi.org/10.31293/ddk.v21i1.4698.

Fernanda D (2003) Pengembangan kualitas pelayanan publik di daerah. Jurnal Administrasi Publik 2 (2):175-202. https://journal.unpar.ac.id/index.php/JAP/article/view/1525.

Gabrilin A (2018) Zumi Zola divonis 6 tahun penjara. Kompas, 6 December. [Accessed 08 June 2021]. https://nasional.kompas.com/read/2018/12/06/12475621/zumi-zola-divonis-6-tahunpenjara?page=all.

Gie TL (2006) Etika Administrasi Pemerintahan. Jakarta: Universitas Terbuka.

Hastiyanto F (2017) Etika dan akuntabilitas sektor publik. Spirit Publik: Jurnal Administrasi Publik 12 (2):75-82. https://doi.org/10.20961/sp.v12i2.16244.

Haddad RSM \& Hijran M (2017) Model kepemimpinan politik sunda dalam konteks pendidikan politik. Prosiding Konferensi Nasional Kewarganegaraan III, 11 November 2017. Yogyakarta: Konferensi Nasional Kewarganegaraan, 326-337.

Humas Bandung (2018) Wali kota gaul yang sarat prestasi, 16 January. [Accessed 02 January 2021]. https://humas.bandung.go.id/profil/wali-kota-gaul-yang-sarat-prestasi.

Ismiyarto (2016) Etika dan penyelenggaraan pelayanan publik. Suara Khatulistiwa 1-16.

Keban YT (2014) Enam Dimensi Strategis Administrasi Publik, Konsep, Teori dan Isu (Edisi Ketiga). Yogyakarta: Gavamedia.

Kementerian PANRB (2010) Peraturan Presiden Republik Indonesia Nomor 81 Tahun 2010 Grand Design Reformasi Birokrasi 2010-2025. Jakarta: Peraturan Presiden 1-38.

KPK (2020) Statistik penindakan. KPK, 01 January. [Accessed 02 January 2021]. www.kpk.go.id/id/ statistik/penindakan.

Kusumawati MP (2019) Harmonisasi antara etika publik dan kebijakan publik. Jurnal Yuridis 6 (1):1-23. http://dx.doi.org/10.35586/jyur.v6i1.794.

Lontoh G, Kasenda V, \& Kairupan J (2019) Etika pemerintahan dalam pelayanan publik (studi di Kantor UPTD Samsat Tondano Kabupaten Minahasa). Jurnal Eksekutif 3 (3).

Lusiawati I (2020) Public relations dalam etika dan etis manajemen. Jurnal Ilmiah TEDC 14 (1):35-42. https://ejournal.poltektedc.ac.id/index.php/tedc/article/view/344.

Maani KD (2010) Etika pelayanan publik. Jurnal Demokrasi 9 (1):61-70. 
Muchtarom M (2012) Fenomena pemilukada, etika politik dan nilai moral kekuasaan. PKN Progresif 7 (1):46-53.

Nugroho I (2013) Mengembangkan etika kepemimpinan: Fenomena pada jabatan publik. Diskusi Bulanan Malang Corruption Watch (MCW). Universitas Widyagama Malang, 20 Februariy 2013.

Paisa L, Gosal R, \& Monintja D (2019) Etika pemerintahan dalam meningkatkan kinerja Aparatur Sipil Negara. Jurnal Eksekutif 3 (3):1-10.

Pitriyanti D \& Harsasto P (2018) Kepemimpinan Ridwan Kamil di Kota Bandung tahun 2013-2018: Kajian inovasi kebijakan kepemimpinan adaptif. Journal of Politic and Government Studies 8 (2):101-110.

Raco J (2018) Metode Penelitian Kualitatif: Jenis, Karakteristik Dan Keunggulannya. Jakarta: Grasindo. Ryn (2021) Kasus Edhy Prabowo, KPK Sita Rp52,3 Miliar dari Bank. CNN Indonesia, 18 March. [Accessed 08 June 2021]. https://www.cnnindonesia.com/nasional/20210315125147-12-617569/ kasus-edhy-prabowo-kpk-sita-rp523-miliar-dari-bank.

Sugiyono (2015) Metode Penelitian Kombinasi (Mix Methods). Bandung: Alfabeta.

Sumarto RH (2017) Etika publik bagi kepemimpinan pemerintah daerah. PUBLISIA (Jurnal Ilmu Administrasi Publik) 11 (1):92-105. https://doi.org/10.26905/pjiap.v2i2.1929.

Santoso T \& Dewi MP (2019) Etika Aparatur Sipil Negara dalam membangun good governance. Transparansi: Jurnal Ilmiah Ilmu Administrasi 2 (2):179-187. https://doi.org/10.31334/ transparansi.v2i2.648.

Sari M \& Asmendri (2020) Penelitian kepustakaan (library research) dalam penelitian pendidikan IPA. Natural Science: Jurnal Penelitian Bidang IPA dan Pendidikan IPA 6 (1):41-53. https://doi. org/10.15548/nsc.v6i1.1555.

Satria HS (2020) Kebijakan kriminal pencegahan korupsi pelayanan publik. Integritas: Jurnal Antikorupsi 6 (2):169-86. https://doi.org/10.32697/integritas.v6i2.660.

Setiawan A \& Fauzi EA (2019) Etika kepemimpinan politik dalam penyelenggaraan pemerintahan Indonesia. Jurnal Pemerintahan dan Kebijakan 1 (1):1-12. https://doi.org/10.18196/jpk.v1i1.7614.

Taufiqurokhman \& Satispi E (2018) Teori dan Perkembangan Manajemen Pelayanan Publik. Tanggerang Selatan: UMJ Press.

Widyani AAD (2020) Etika Bisnis Perspektif Teori Dan Praktis. Bali: CV. Noah Aletheia.

Yuningsih T (2019) Etika Administrasi Publik. Program Doktor Administrasi Publik. Semarang: Administrasi Publik, Fisip, Universitas Diponegoro.

Yunus NR (2014) Etika dan moralitas politik anggota dewan. Jurnal Ilmu Syariah Mizan 2 (2):255-274. https://doi.org/10.32507/mizan.v2i2.148.

Yusuf IM (2017) Etika dalam wujud akuntanbilitas penyelenggaraan pemerintah. Dinamika 4 (4):54857. http://dx.doi.org/10.25157/dinamika.v4i4.877. 